UDC $336.7 ; 339.7 ; 339.9$

DOI: https://doi.org/10.37320/2415-3583/17.14

Filon Mykhailo

Ph.D.,

Senior Lecturer at the Department of Political Science and Law

South Ukrainian National Pedagogical University

named after K.D. Ushynsky

Borsuk Yevheniia

Student

South Ukrainian National Pedagogical University named after K.D. Ushynsky

\title{
CRYPTOCURRENCY AS A VIRTUAL SOLUTION OF THE PROBLEM OF DOUBLE COSTS. CRYPTOCURRENCY IN UKRAINE
}

The article considers the concept of cryptocurrency, its history, features, pros and cons, ways of distribution of cryptocurrency in the world and in Ukraine. The problematic issues of making virtual currencies are considered, in particular, why this issue is relevant today. Cryptocurrency is an opportunity to look at economic issues from a new angle. Its emergence is due to the needs of the time. Undoubtedly, this is an actual technical achievement. Opportunities and popularity are currently growing at a rapid pace. It is similar in characteristics to ordinary money but has a number of features that are becoming increasingly popular today. There are many ways to earn cryptocurrency and make a profit from it. Cryptocurrency is a new word in money circulation. We can assume that cryptocurrency may soon become an alternative to traditional means of payment.

Key words: cryptocurrency, bitcoin, coin, blockchain, mining, darknet, virtual currencies, electronic money.

JEL classification: F01, F31, F39, G32, G35

Formulation of the problem. The problem of rapid development of virtual currencies in recent years has reached a global level. Due to economic problems and financial crises, people are increasingly trying to save money by turning to virtual cryptocurrencies.

Analysis of recent research and publications. Scientists focus on the essence of cryptocurrency, its transparency and solving the problem of double costs. They see virtual money as an alternative to traditional money. Various aspects of this problem are reflected in the works of such scientists as M.A. Kutsevol, O.A. Shevchenko-Naumov, M. Likhachov, P. Mashchenko, David Chaum.

Setting objectives. An important part of the problem in the study of cryptocurrencies is the lack of understanding of what hides its reverse side that is why the purpose of the article is to study the concept of cryptocurrency, its history and features.

Presenting main material. Cryptocurrency is the name of a distributed and decentralized system of secure exchange and transfer of digital banknotes based on cryptographic means. The banknotes of such a system can be exchanged for fiat money at the market rate [1].

Cryptocurrency is a fast and reliable system of payments and remittances, based on the latest technologies. It is beyond the control of any government.

Cryptocurrency is a medium of exchange, like ordinary currencies, but is designed to exchange digital information, which has become possible due to certain principles of cryptography (used to ensure operations and control the creation of new coins) [2].

To date, there are many cryptocurrencies, consider the most popular:

1. Bitcoin (exchange ticker - BTC, sometimes - XBT) is the first in history and the most popular cryptocurrency in the world.
2. Ethereum (ETH) is a digital currency platform for creating decentralized online services based on blockchain (Dapps), operating on the basis of smart contracts.

3. Ripple (XRP) cryptocurrency is used in the system of gross settlements in real time, as well as for currency exchange and money transfers.

4. Bitcoin Cash appeared as a result of the hard fork "alternative to bitcoin".

5. IOTA is a cryptocurrency of the exchange network project for the Internet of Things [4].

The first cryptocurrency was the Bitcoin system. In 2008, the inventor, who chose the pseudonym Satoshi Nakamoto, created a way to solve the problem of double costs without the involvement of a third party. His invention is the electronic payment system Bitcoin. Later, with the use of such innovations, which Bitcoin had introduced, a number of other cryptocurrencies were created, but some specific parameters of the algorithms embedded in their work were differed from Bitcoin. The word "bitcoin" was first heard in 2008. The combination of two English words "bit" as a unit of measurement of information that we write, for example, on a flash drive, and "coin". At the beginning of the emergence of virtual cryptocurrencies, bitcoins were sold for 0.8 USD, and in December 2017, bitcoin cost more than 20,000 USD. There are certain rules in this system. To join this computer system you need to download the bitcoin wallet application to your phone. Access to it is not a PIN code, as in a bank card, but code phrases. After downloading the program, your phone connects to millions of others, and you can transfer money to a person at the other end of the world not via a bank, but directly. In the world of cryptocurrency, the money transfer operation, which is usually carried out by banks, is performed by computers. They can be anywhere in the world, and anyone can do it, but for each of the computers the system arranges a test, the so-called competition, and selects only the most powerful, which are 
best able to protect money transfers from outside interference. If the computer wins, its owner receives a reward. This process is called mining. The total number of bitcoins is limited, there will be no more than 21 million. And they will be mined until 2140, so the system is programmed. Therefore, people around the world are competing to get into this chain. Already at the moment, big businessmen in China have built whole mines, huge rooms with miners watched by one or two people. They are extracted at home using the same computers. Due to the load on the grid, several cases of fires were recorded. The crypt can be used for trading as a long-term investment or trading tool. The crypto market is volatile; the exchange rate of some coins is actively jumping up and down. Therefore, with the help of cryptocurrencies you can make good money.

The unit of measurement in this system is a "Coin". Cryptocurrency has no real expression like metal coins or paper banknotes. This money exists exclusively in digital form. The turnover of such currency takes place according to the "blockchain" system. This system is a database distributed over millions of personal computers around the world. It is not hosted on a single server or hard drive, but divided into nodes. It is supported by active network members - regular wallet users. Thus storage and record of the information at the address of cryptocurrencies occurs on all devices at once that guarantees transparency and openness of transactions. It is a way for a group of people to build relationships on their own, rather than trusting others to manage their money.

Ways to earn cryptocurrency:

- Cranes - services for the distribution of Bitcoin and other coins for small tasks: solving captchas, web surfing and so on.

- Bounty - the process of advertising new ICO-projects through posting, reposting, translation. Initially, you receive free tokens, which will soon become a full-fledged cryptocurrency.

- Posting / copywriting - participants of Steemit and Golos services receive a reward in the form of internal cryptocurrency. In the future, it can be exchanged [3].

In order to earn cryptocurrencies, you only need to choose the way you like and make every effort to develop in this area.
Each of the existing types of cryptocurrencies has both advantages and disadvantages inherent in them all together.

Advantages of cryptocurrencies:

- Anonymity of transactions - there is no information about the owner of the crypto wallet (there is only a wallet number);

- The open source algorithm allows anyone to get it;

- Decentralized nature, lack of a single digital bank, lack of control over transactions and payments;

- Not prone to inflation (limited number of coins);

- Security, it cannot be copied.

Disadvantages of cryptocurrency:

- Negative actions against it are possible on the part of national regulators

- High price variability due to the specifics of use

- Loss of the password to the electronic crypto wallet or its inoperability lead to complete and irreversible loss of all coins

In general, cryptocurrencies are characterized by the same features as modern money, namely:

- cryptocurrencies are universal;

- it is an exchange medium;

- cryptocurrencies can be accumulated;

- cryptocurrencies perform a calculation function.

In Ukraine, due to greater interest in the capabilities of this system, there are already stores where you can pay with bitcoins. Similarly, in almost all terminals you can top up your Bitcoin account. Unfortunately, the cryptocurrency bitcoin does not currently have a specific legal status in Ukraine.

At the same time, according to public data from the declarations of public figures, it can be seen that they already use cryptocurrency as an investment asset.

Consider the exchange rate of bitcoin to the hryvnia in the period from November 2017 to January 2021:

Observing the trend of growth and decline of bitcoin in the period from 2017 to 2021 , we can conclude whether to use video cards and a computer's CPU to extract currency.

At the beginning of the emergence of bitcoins, the complexity of cryptocurrency mining was minimal, which allowed to establish the mining process using the computer's CPU. Bitcoins could be mined without much effort, the rate of which until 2015 did not exceed 500 UAH per 1 BTC. Already in 2019, the cryptocurrency rate went up,

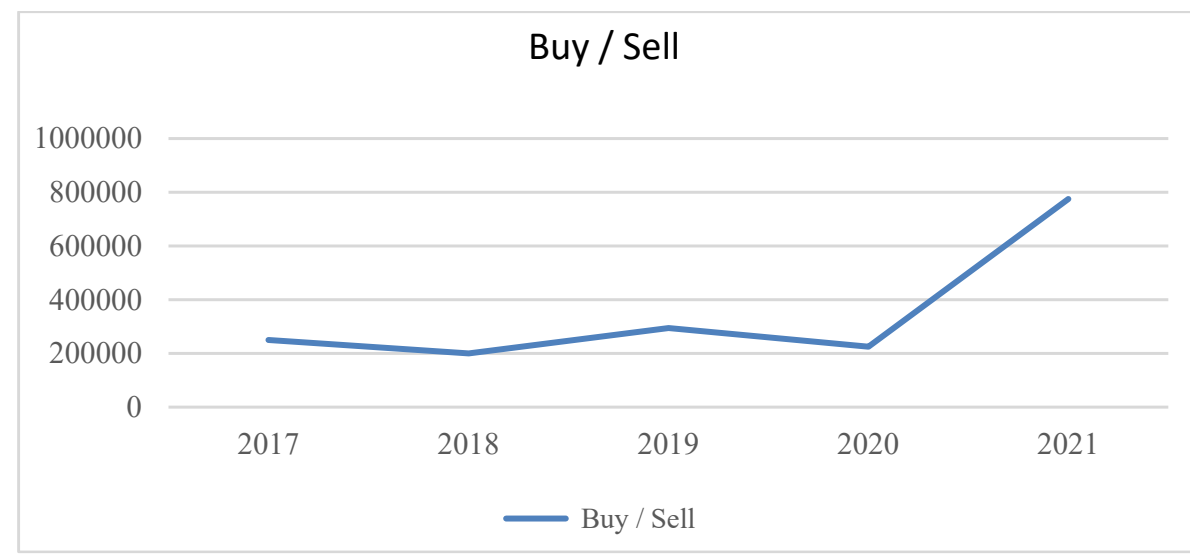

Figure 1 - The exchange rate of bitcoin to the hryvnia in the period from November 2017 to January 2021 
the popularity of virtual coins increased, and the complexity of mining jumped. Extracting bitcoins using the computer's CPU has become a futile task. Along with processors, participants in the crypto network used GPUs (video cards), which were better suited for mining cryptocurrencies. Video card - a graphics processor capable of performing many identical tasks. Since 2016, video cards have ceased to bring the expected profit, due to the sharp rise in the price of Bitcoin, the growing popularity of cryptocurrencies and, consequently, the increasing complexity of mining. Miners began to assemble farms, i.e. special complexes, which included from 4 or more video cards. In December 2017, when the cryptocurrency exchange rate exceeded the 20,000 mark, the relevance of using farms on the GPU was minimized. Buying expensive equipment and spending time extracting BTC virtual currency with GPU farms is futile, but by early 2021, the cryptocurrency rate has skyrocketed, and the situation in this market will change in the near future.

At the same time, the cryptocurrency market has a dark side, their popularization is not accidental. It is anonymity that has two sides. On the one hand, it is an opportunity not to pay taxes. On the other hand, this is the main method of payment in the darknet. Clarinet is the Internet that everyone uses every day. Darknet is the Internet, which can be accessed only through a special browser. This is the human trafficking, trade in passports, criminal services.

Information is an expensive commodity in the 21 st century. Information exchange, where lots are documents of state importance, correspondence, compromising materials, databases, all this can be bought for bitcoins.

The motto of darknet forums is "the one who owns information owns the world." Darknet forums bring together people of different interests, from lawyers, doctors, engineers to criminals. Everyone shares experiences, and everything remains anonymous, they offer many services for bitcoin.

Conclusions. Cryptocurrency is an opportunity to look at economic issues from a new angle. Its emergence is due to the needs of the time. Undoubtedly, this is an actual technical achievement. Opportunities and popularity are currently growing at a rapid pace. It is similar in characteristics to ordinary money, but it has a number of features that are becoming increasingly popular today. Therefore, there are many ways to earn cryptocurrencies and make a profit from them. The main advantages of this type of currency are the lack of control and restrictions on issuance, the ability to generate currency independently through mining, complete anonymity, protection from inflation. However, despite all the advantages, this type is one of the most common types of payment in the criminal world.

On the positive side, in some European cities, local authorities have begun accepting some of the utility bills and taxes in bitcoins. And now you can pay for the services of a dentist, shopping in the store and much more for bitcoins.

Thus, cryptocurrency is a new word in money circulation. Based on this, we can assume that cryptocurrency may soon become an alternative to traditional means of payment.

\section{References:}

1. Likhachov M. Skromna charivnist bitkoina: ukrainski realii vykorystannia krypto valiut. Forbes Ukraina. Available at: http://forbes.net.ua/ua/opinions/1428255-skromnacharivnist-bitkoina-ukrayinski-realiyivikoristannyakriptovalyut-utm medium= social\&utm_source=facebook.com\&utm_campaign=skromna-charivnistbitkoinaukrayinski-realiyi-vikoristannya-kriptovalyut (accessed 10 November 2020).

2. Kutsevol M.A. The concept and economic nature of cryptocurrency / M.A. Kutsevol, O.A. Shevchenko-Naumov. Available at: http://ir.kneu.edu.ua:8080/bitstream/2010/16391/1/79-85.pdf (accessed 17 December 2020).

3. What is a cryptocurrency? Available at: https://prostocoin.com/blog/what-is-cryptocurrency (accessed 13 December 2020).

4. Five popular cryptocurrencies. Available at: https://forklog.com/top-5-samyh-populyarnyh-kriptovalyut/ (accessed 10 October 2020).

5. Exchange rate. Available at: https://charts.finance.ua/ru/currency/bitcoin/-/1/btc (accessed 11 February 2021).

\section{Список використаних джерел:}

1. Ліхачов М. Скромна чарівність біткоіна: українські реалії використання крипто валют. Forbes Україна. URL: http://forbes.net.ua/ ua/opinions/1428255-skromnacharivnist-bitkoina-ukrayinski-realiyi-vikoristannyakriptovalyututm_medium=social\&utm_source=facebook . com\&utm campaign=skromna-charivnist-bitkoinaukrayinski-realiyivikoristannya-kriptovalyut (дата звернення: 10.11.2020).

2. Куцевол М.А. Поняття та економічна природа криптовалюти / М.А. Куцевол, О.А. Шевченко-Наумова. URL: http://ir.kneu.edu.ua:8080/bitstream/2010/16391/1/79-85.pdf (дата звернення: 17.12.2020).

3. Що таке криптовалюта? URL: https://prostocoin.com/blog/what-is-cryptocurrency (дата звернення: 13.12.2020).

4. П’ять популярних криптовалют. URL: https://forklog.com/top-5-samyh-populyarnyh-kriptovalyut/ (дата звернення: 10.10.2020).

5. Курс валют. URL: https://charts.finance.ua/ru/currency/bitcoin/-/1/btc (дата звернення: 11.02.2021). 
Філон М.М., Борсук С.Г. Південноукраӥнський національний педагогічний університет імені К.Д. Уиинського

\section{КРИПТОВАЛЮТА - ВІРТУАЛЬНЕ РІШЕННЯ ПРОБЛЕМ ПОДВІЙНИХ ВИТРАТ, КРИПТОВАЛЮТА В УКРАЇНІ}

У статті розглядається поняття, щзо таке криптовалюта, їі історія, особливості, позитивні та негативні сторони. Розповсюдження криптовалюти в світі та в Україні. Розглядаються проблемні питання віртуальних валют, і чому ие питання актуальне на сьогоднішній день. Криптовалюта - засіб обміну, як $і$ звичайні валюти, але призначена для обміну ицифровою інформацією, щчо стало можливим завдяки певним принципам криптографії (використовується для забезпечення операцій та контролю створення нових монет). Першою криптовалютою була система Bitcoin. Криптовалюта потрібна для платежів. Але не просто транзакції, а анонімні, швидкі і прямі транзакиії. Здійснюються, як між приватними особами, так $і$ для купівлі товарів або послуг в інтернеті. «Викрасти» криптовалюту з гамания практично неможливо. Так як всі операції незворотні і використовують приватні ключі, перехопити їх або зламати неможливо. Вінсоіп і іншу крипту розглядають в якості інвестиційного активу за рахунок коливань курсу $i$ загального зростання популярності. Криптовалюти автоматизують грошові відносини та найголовніше - роблять їх прозорими. Одиницею виміру в цій системі є «Коіни» («монети»). Криптовалюта не має ніякого реального висловлювання на кшталт металевих монет або паперових банкнот. Ці гроші існують виключно в циифровому вигляді. Оберти такої валюти відбуваються за системою «блок-чейна» («замкнений ланцюг»). Ця система являє собою розподілену за мільйонами персональних комп'ютерів у всьому світі базу даних. При изьому зберігання $i$ запис інформації при зверненні криптогрошей відбувається на всіх пристроях відразу, щзо гарантує прозорість $і$ відкритість транзакиій. Якщо простіше - ие спосіб для окремої групи людей самостійно будувати відносини на взаємній довірі, а не довіряти управління своїми грошима іншим. Криптовалюта - можливість поглянути на економічні питання під новим кутом. Ї̈ виникнення обумовлено потребами часу. Безсумнівно, ие актуальне технічне досягнення. Можливості та популярність на даний момент зростає на великій швидкості. Вона по характеристикам схожа на звичайні гроші, але має ряд можливостей, які надають все більшої популярності в наш час.

Ключові слова: криптовалюта, біткоӥни, коін, блок-чейн, майнінг, даркнет, віртуальні валюти, електронні гроші. 